\title{
Economic Impacts of Climate Change on Florida: Estimates from Two Studies ${ }^{1}$
}

\author{
Tatiana Borisova, Norman Breuer, and Roy Carriker²
}

\section{Introduction}

The issue of climate change has attracted Florida's policymakers. Executive Order 07-127, signed by Governor Charles Crist in 2007, calls for the reduction of state greenhouse gas emission by $80 \%$ from the 1990 level by 2050 (Florida Governor's Action Team on Energy and Climate Change 2008). In June of 2008, Governor Crist hosted a Climate Change Summit after Chief Financial Officer Alex Sink and Commissioner of Agriculture and Consumer Services Charles Bronson hosted a series of Conversations on Climate Change in 2007.

Despite these efforts, many skeptics of climate change remain among Florida decision-makers and the general public concerning the effect of human activities on climate. Some argue that the price of reducing carbon emissions is too high compared to the uncertain benefits and the limited effects of our actions on climate (McCollum 2007).

This document focuses on one piece of the policy-making puzzle related to climate change: possible economic costs for the state of Florida associated with climate change projections (Stanton and Ackerman 2007).

\section{What Does Science Tell Us about Climate Change?}

With a high degree of certainty, science tells us that human activities are changing the composition of Earth's atmosphere, increasing the levels of greenhouse gases like carbon dioxide $\left(\mathrm{CO}_{2}\right)$, mostly by fossil fuel combustion, agricultural activities, and land use change. An "unequivocal" global average warming of about $1.0-1.7^{\circ} \mathrm{F}$ occurred during the period of 1906-2005. A growing number of scientific analyses indicate, but cannot confirm with $100 \%$ certainty, that rising levels of greenhouse gases in the atmosphere are contributing to climate change, as theory predicts (U.S. EPA 2007).

As emission of greenhouse gases continues, and with the knowledge that major greenhouse gases remain in the atmosphere for decades or even centuries, climate scientists can predict with near-certainty that the concentration of greenhouse

1. This is EDIS document FE787, a publication of the Food and Resource Economics Department, Florida Cooperative Extension Service, Institute of Food and Agricultural Sciences, University of Florida, Gainesville, FL. Published December 2008. Please visit the EDIS website at http://edis.ifas.ufl.edu.

2. Tatiana Borisova, assistant professor, Food and Resource Economics Department, University of Florida, Gainesville, FL; Norman, associate research scientist, Rosenstiel School of Marine and Atomospheric Science, Univeristy of Miami, Coral Gables, FL; and Roy Carriker, Professor, Food and Resource Economics Department, University of Florida, Indian River Research and Education Center, Fort Pierce, FL, Florida Cooperative Extension Service, Institute of Food and Agricultural Sciences, University of Florida, Gainesville, FL.

The Institute of Food and Agricultural Sciences (IFAS) is an Equal Opportunity Institution authorized to provide research, educational information and other services only to individuals and institutions that function with non-discrimination with respect to race, creed, color, religion, age, disability, sex, sexual orientation, marital status, national origin, political opinions or affiliations. U.S. Department of Agriculture, Cooperative Extension Service, University of Florida, IFAS, Florida A. \& M. University Cooperative Extension Program, and Boards of County Commissioners Cooperating. Larry Arrington, Dean 
gases will continue to increase. Hence, it is very likely that average temperatures and sea levels will continue to rise. However, science does not yet give any definitive answers to questions regarding how much warming will occur, where it will occur most, how fast it will occur, and how the warming will affect the rest of the climate system, including precipitation patterns and storms (U.S. EPA 2007).

\section{Climate Change Impacts}

The Intergovernmental Panel on Climate Change (IPCC), a Nobel Peace Prize winner for 2006, includes more than 2,000 scientists. It was established by the World Meteorological Organization (WMO) and the United Nations Environment Program (UNEP) "to provide....an objective source of information about climate change" based on "the latest scientific, technical, and socio-economic literature produced worldwide" (IPCC 2004). IPCC identifies the following impacts of climate change on North America (Field et al. 2007):

- An increase in the rate of sea level rise, leading to more floods, storm surge flooding, and shoreline erosion; population growth and the rising value of infrastructure in coastal areas increases vulnerability to climate variability and future climate change; coastal habitats and dependent species are threatened by sea level rise, while human-made structures prevent vulnerable species from migrating inland

- Shortages of the over-allocated water resources and increased competition among agricultural, municipal, industrial, and ecological uses

- Health impacts and mortalities due to high temperatures, extreme weather, and infectious diseases

- Intensified wildfire and insect outbreaks in warmer climates with drier soils and longer growing seasons

(Because climate science is complex, there has been much confusion among concerned citizens, elected officials, and scientists from other disciplines about the credibility of climate forecasts and uncertainty regarding "who to believe" in the face of conflicting reports. The combined topics of global warming and climate change have been the subject of misinformation and disinformation. The IPCC website provides a wealth of information and a solid basis for the credibility of its reports. An especially helpful report of the IPCC is Climate Change 2007: Synthesis Report-Summary for Policymakers, available online at http://www.ipcc.ch).

The forecasts of climate change and its impacts become less precise as one changes focus from the global to regional and local scales. However, the effects identified above for North America are similar to the effects summarized by the United States Environmental Protection Agency (U.S. EPA) for the Southeast and Gulf Coast regions: increased coastal erosion; greater risks of flooding from sea level rise, storm surge, and extreme precipitation events; increased disturbances (such as fire and insect outbreaks); higher summer heat; and reduced winter cold stress (U.S. EPA 2007b).

Specifically for Florida, warming climate could raise sea level by one to three feet (or 12 to 36 inches) over the next century (U.S. EPA 2002). Even a one-foot increase has the potential to erode 100 to 200 feet of the states beaches, and lead to inundation of the coastal areas. Although most of Floridas urban development is located above elevations of 4.5 feet above sea level, the areas with elevations between 4.5 and 11 feet (such as the Keys, barrier islands, and the areas around Biscayne Bay and Charlotte Harbor) will likely experience increased flooding from higher sea levels and increased storm intensity (U.S. EPA 2002). Sea level rise also puts the water supply in the regions along the south coast at risk. The Biscayne Aquifer that supplies most of South Florida (Miami-Dade, Monroe, and parts of Broward Counties) is recharged mostly by freshwater from the Everglades. Sea level rise could lead to saltwater flooding in parts of the Everglades, threatening both that ecosystem and the aquifer that lies beneath it with salt water intrusion (U.S. EPA 2002). Furthermore, sea level rise would impact coastal habitats critical for Floridas coastal fisheries, waterfowl, shorebirds, sea turtles, manatees, and other wildlife species. Climate change is also expected to lead to an increase in marine diseases and harmful algal blooms (National Wildlife Foundation 2006). 
Studies report that the vulnerability of a region to climate change impacts depends on the effectiveness and timing of adaptation and mitigation. Adaptation refers to protection measures that decrease the effect of climate impacts (such as adjustments in agricultural crop and variety patterns or investments in critical infrastructures to minimize damage from floods). Mitigation refers to measures to slow down the process of global climate change by reducing greenhouse gas concentrations in the atmosphere (e.g., planting trees or capturing carbon dioxide from atmosphere and injecting it under the ground).

\section{Estimating Economic Impacts of Climate Change}

A variety of economic estimates have been produced related to the costs of climate change, and mitigation and adaptation measures. These estimates often diverge due to differences in the assumptions made in the studies, definitions of how the economy works, and data sets employed. Key assumptions (Weyant 2000) that explain the divergence of economic estimates made by different economic studies include the following:

- Projections of greenhouse gas emissions (current and future)

- Climate policies put in place to achieve emissions reductions

- Effects of advances in technology on greenhouse gas emissions

- Degree of inclusion of the environmental impacts of climate change

- Available choices when presented with rising energy prices

Studies can measure the economic impacts of climate change using different economic indicators (e.g., resource costs, percent change in Gross Domestic Product, or a discounted present value of consumption), which are selected based on the interests and objectives of the model users. Economic models may differ by the range of environmental impacts considered (such as impacts on agriculture, forestry, ecosystems, wildlife, biodiversity, fisheries, etc.) and the treatment of market and non-market impacts of climate change. Market impacts refer to the changes in market prices and demands, for example, in agriculture and forestry. Non-market impacts refer to the changes that do not affect marketed products, such as changes in ecosystems, human health, wildlife, and biodiversity. Economics offers methods to value nonmarket impacts, and although these methods are widely used, they are controversial (Weyant 2000). There are also considerable uncertainties about the magnitude of climate change and its impacts, the sectors that will be affected, societal values (such as the value of human life), and model structure. To understand the differences in conclusions offered by various studies, it is important to examine how the studies treat these uncertainties (Weyant 2000).

Climate projections produced by IPCC differ among the six main scenarios that incorporate assumptions about future greenhouse gas emission, future technological and economic development, land-use changes, and other parameters. For example, the difference in assumptions for the scenarios named "B1" and "A2" lead to a $1.6^{\circ} \mathrm{C}$ difference in the projection of global average temperature increase (Table 1).

\section{Climate Change and the Florida Economy}

Only two studies were found that examine the potential economic impacts of climate change specifically on Florida's economy: Stanton and Ackerman (2007), and Harrington and Walton (2008). The studies differ in the climate change scenarios used, time horizons considered, geographical scales and economic sectors examined, and the methodologies employed. These differences complicate the comparison between the studies. Also, economic impacts are measured in 2006 U.S. dollars in Stanton and Ackerman (2007) and in 2005 and 2006 U.S. dollars in Harrington and Walton (2008). The consumer price index for housing (BLS 2008) was used to convert all the estimates to 2006 U.S. dollars.

Stanton and Ackerman (2007) operate with two climate scenarios: the "rapid stabilization" and 
"business-as-usual" scenarios (Table 2). The rapid stabilization scenario assumes that by 2050 , global greenhouse gas emissions will be reduced by $50 \%$, and U.S. emissions will be reduced by $80 \%$ from the current levels, which would declerate the climate warming trend (this scenario is more optimistic than the "low emission" B1 scenario developed by IPCC). This scenario also assumes no changes in precipitation and hurricane intensity in comparison with the currently observed patterns.

In the pessimistic business-as-usual scenario (based on A2 scenario produced by IPCC), global and U.S. greenhouse gas emissions will increase based on historic trends. The increase in annual average temperature is higher than in the rapid stabilization scenario, and the sea level rise is greater (Figures 1 and 2). In addition, the pessimistic scenario incorporates a $10 \%$ decrease in overall precipitation for Florida, with increased duration of droughts. The pessimistic scenario also projects increases in hurricane intensity, with more Category 4 and 5 hurricanes, coupled with higher storm surges due to sea level rises.

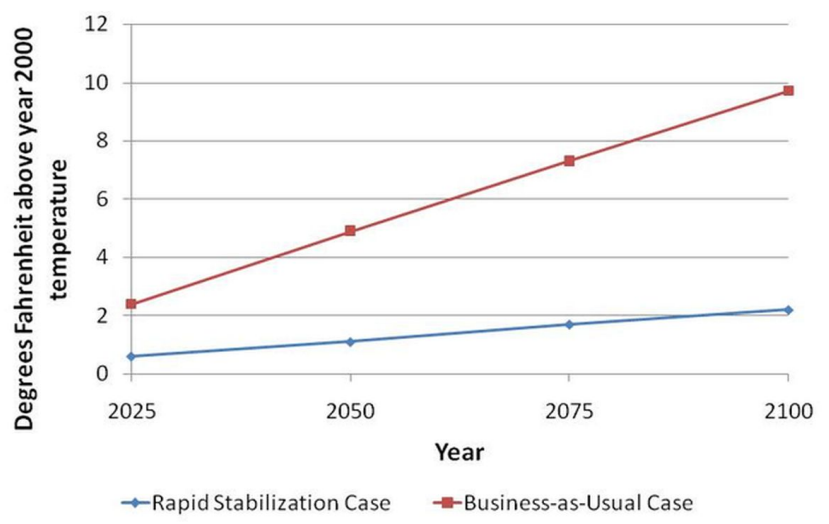

Figure 1. Two future climate scenarios for Florida based on Stanton and Ackerman (2007): Annual average temperature (in degrees Fahrenheit above year 2000 temperatures).

After selecting the "rapid stabilization" and "business-as-usual" scenarios for purposes of analysis, the authors examine the potential impacts of climate change on Florida's economy for each scenario. The study focuses on the loss of tourism revenue, increased hurricane damages, the value of residential real estate that is at risk from sea level rise, and increased costs of electricity generation as

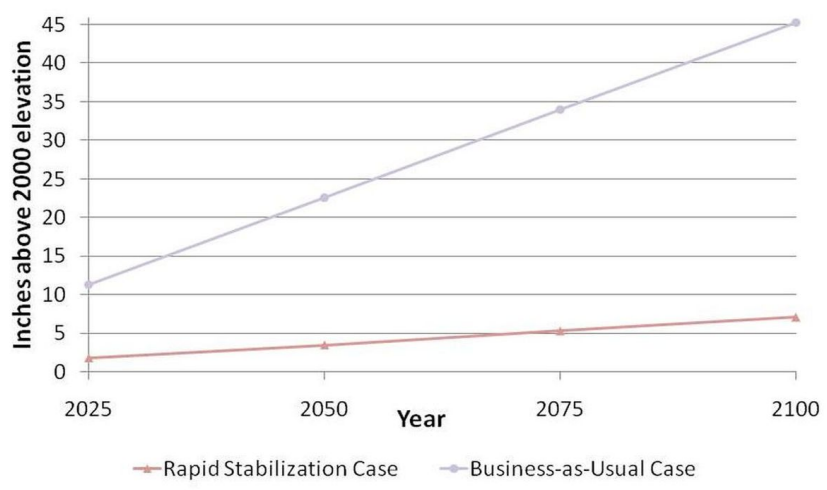

Figure 2. Two future climate scenarios for Florida based on Stanton and Ackerman (2007): Sea level rise (in inches above year 2000 elevation).

temperatures and air conditioning requirements rise. The estimates are made for the period between 2008 and 2100 .

The second study by Harrington and Walton (2008) focuses on the period 2008-2080, and examines one consequence of climate change-sea level rise. As high-end estimates, IPCC projects sea level rises of 3.96-25.56 inches by 2080. The low-end estimates are developed using historical tidal gauge data from six gauge stations along the Florida coast, equal to $9.96-13.56$ inches by 2080 . Given these sea level rise projections, the authors examine damage costs and per acre value of lands at risk in six coastal Florida counties: Dade, Dixie, Duval, Escambia, Monroe, and Wakulla.

Neither of the studies account for the adaptive behaviors that people could take in response to the climate change, which could reduce economic impacts of climate change.

\section{Impact of Hurricanes}

Based on data for 1990-2006, Stanton and Ackerman (2007) estimated that currently the impact of an "average hurricane year" is $\$ 3.7$ billion (in 2006 U.S. dollars) and eight deaths (at the 2006 level of population). These numbers were adjusted upward for both the rapid stabilization and business-as-usual scenarios based on three assumptions. First, a previous study by Pielke and Landsea (1998) showed that hurricane damages rise approximately in proportion to the Gross State Product. This logic was extended by Stanton and Ackerman (2007) to assume 
that hurricane deaths are proportional to state population. Second, following the conclusions from a study on economics of hurricanes in the United States by Nordhause (2006), it is assumed that for every 3.3 feet (one meter) of sea level rise, the economic damages from hurricanes double. Third, calculations from the same study by Nordhause (2006) show that doubling atmospheric carbon dioxide results in doubling hurricane damages. Combining these effects, Florida's projected hurricane damages for 2050 is $\$ 24$ billion and 18 deaths for the rapid stabilization case, and $\$ 49$ billion and 37 deaths in the business-as-usual case. The annual cost difference between the scenarios is $\$ 25$ billion and 19 extra deaths in 2050, and \$104 billion and 37 extra deaths in 2100 (all monetary estimates are done in 2006 U.S. dollars; however, no discounting of future costs to 2006 dollars is conducted).

Harrington and Walton (2008) employ a different methodology, and estimate the future changes in the hurricane return period (i.e., the average number of years between events) given the low-end and the high-end sea level rise scenarios. Both scenarios show a dramatic decreasing trend in the hurricane return period (in other words, hurricanes become more frequent). For example, given a sea level rise of 12.24 inches, a 7-foot high storm surge (similar to the surge of Hurricane Wilma in Dade County) could be expected, on average, to occur every 21 years instead of every 76 years (as projected, given current climate pattern). Next, historical damage costs for eight hurricanes between 2004 and 2005 were examined based on insurance claims data provided by the Florida Office of Insurance Regulation. A representative hurricane was selected for each of the six counties in the study, and the increases in the damage values for these representative hurricanes due to sea level rise were estimated (Table 3). Note that, in contrast to Stanton and Ackerman (2007), the study does not attempt to account for future changes in population or built environment, and the potential increases in the strength of hurricanes due to climate changes.

\section{Real Estate}

The Stanton and Ackerman estimate of the impact of climate change on real estate is based on two assumptions: (1) the value of real estate will grow uniformly in all parts of the state in proportion to the Gross State Product and (2) the fraction of the state's residential property at risk is proportional to the extent of sea level rise. The 2000 estimate of the residential real estate vulnerable to a 27 -inch sea level rise provides a starting value for the estimations ( $\$ 130$ billion). The difference in the value of residential real estate at risk of flooding between the rapid stabilization and business-as-usual scenarios reaches $\$ 56$ billion annually by 2100 , which is almost $1 \%$ of the Gross State Product. Note that the study does not account for the value of the property abandoned due to sea level rise.

Harrington and Walton (2008) focus on area, value, and per acre value of land at risk for three counties: Dade, Duval, and Escambia (Table 4). The authors used county-specific estimates of sea level rise for 2080, a geographic information system developed by Florida State University to estimate elevation by area, and the Florida Department of Revenue's parcel property values. Note that the estimates do not incorporate the possible increase in the property value over time.

\section{Tourism}

Losses to the tourism industry were estimated only by Stanton and Ackerman (2007). First, for the rapid stabilization scenario (Table 2), the authors used the current growth trend for Florida's Gross State Product and assumed that the share of tourism taxes in the Gross State Product will stay the same (9.6\%). Given this assumption, the Gross State Product will grow six-fold over the next century, and Florida's tourism industry will bring in $\$ 137$ billion in revenues in 2050 and $\$ 668$ billion in 2100 (2006 U.S. dollars).

Using the business-as-usual scenario, the authors assume that the number of tourists coming to the state will gradually decrease by $25 \%$ by 2100 . This assumption is based on the estimated "base" number of tourists coming to Florida independent of the weather. This estimate equals the minimum number of tourists per quarter that visit the state, which falls in the months of October through December. On average, during the last quarter, the 
state receives only $19 \%$ of its total annual number of tourists. If this assumption is true, and at least $19 \%$ of the annual number of visitors come to Florida each quarter independent of the weather, then about $75 \%$ of the annual visitors would continue coming to Florida (4 quarters times $19 \%$ per quarter). The authors also assume that Florida residents will similarly reduce their tourism and recreation activities and spending by $25 \%$. In comparison with the rapid stabilization scenario, Florida's tourism industry will bring $\$ 40$ billion less in annual revenue by 2050 , and $\$ 167$ less by 2100 , an annual loss of $1.2 \%$ and $2.4 \%$ of Gross State Product, respectively (Table 5).

\section{Electricity}

Increase in the cost of electricity generation was estimated only by Stanton and Ackerman (2007). To estimate and compare the cost of electricity generation in the rapid stabilization and the business-as-usual scenarios, Stanton and Ackerman (2007) simulate increases in electricity demand throughout the twenty-first century, driven by increases in population, per capita consumption, and rises in temperature. The authors assume that fuel prices and the cost of new power generation plants stay at the current level. For the rapid stabilization scenario, the simulation assumes an increasing role for renewable energy sources, which will supply $30 \%$ of the electricity consumption by 2100 . In contrast, for the business-as-usual case, the authors assume that the growing demand for electricity will be satisfied using the current fuel mix (mainly fossil fuels). In this scenario, approximately five natural gas plants, four oil plants, and one coal plant would need to be built in the state every year.

In both scenarios, an increase in population and energy demand increases the annual cost of power. However, warming climates in the business-as-usual case account for an additional $\$ 18$ billion per year by 2100. In other words, every additional degree Fahrenheit of warming will cost electricity consumers an extra $\$ 3$ billion per year (Stanton and Ackerman 2007). Given the assumption used by the authors that state population will reach 33 million by 2050 and then remain constant, this translates into about $\$ 90$ per capita per additional degree Fahrenheit.

\section{Other Impacts}

Stanton and Ackerman (2007) discuss other possible impacts of the business-as-usual climate change scenario. For agriculture, after benefiting from a reduction in the number of freezes, crop production will be negatively affected as the climate continues to warm. The authors refer to the U.S. EPA (1997), stating that citrus production in South Florida will begin to decline as a result of temperature increases as periods of dormant growth, necessary for development of the fruit, are reduced. The authors cite several studies of the optimal temperature interval for citrus, tomatoes, and sugarcane growth $\left(68-86^{\circ} \mathrm{F}, 67-77^{\circ} \mathrm{F}\right.$, and $77-79^{\circ} \mathrm{F}$, respectively). As temperatures move away from the optimal intervals, crop production will begin to decline. Agriculture will also be affected by the northward shift of insects and weeds, flooding from sea level rise, and hurricane storm surges. A warmer and drier climate will also increase the agricultural demand for water, competing with other users for water resources that will become more limited.

For forestry, the distribution of forest species will change. For many species, the temperature will rise above their survival limits. Decreased soil moisture and increased evapotranspiration (i.e., the combination of evaporation and plant transpiration) due to warmer weather will also affect many species. Coastal and low-lying forests will be affected by sea level rises.

For fisheries, warmer weather, sea level rise, and more intense (and possibly, more frequent) hurricanes will have a devastating effect on coral reefs and estuaries, on which many fish species depend for reproduction nurseries. This effect will be jeopardized by human-made structures that prevent migration of estuarine species inland.

The Federal Emergency Management Agency estimates that a 1-foot (12 inches) sea level rise would increase flood insurance premiums by 35-60\% (U.S. EPA 2002), with coastal housing at the higher end. As climate changes and hurricanes intensify, it will be harder for homeowners to pay the increased cost of home insurance. Private insurance firms are likely to continue moving out of Florida, 
leaving the government and taxpayers to cover the rising costs of hurricane damages (Stanton and Ackerman 2007).

The transportation sector will also be affected by changing climate in the business-as-usual scenario. Sea level rise and storm surges put port facilities, as well as airports, railways, and roads in low-lying areas, at risk.

For the water system, a hotter and drier climate will increase demand for water while decreasing supply. Sea level rise will increase salt water intrusion, and the groundwater supply will become brackish. Since desalination is expensive and requires large amounts of energy, water supply costs will increase.

The business-as-usual scenario is also associated with large-scale losses of Florida ecosystems due to sea level rise and associated floods and salt water intrusion, higher temperatures and less rainfall, and severe hurricanes. Flooding and migration of ecosystems inland will be problematic due to protective human-made structures which will amplify ecosystem losses.

\section{Conclusions}

Selecting strategies to mitigate and adapt to climate change requires balancing the costs that society will incur now with future benefits and avoided damages. While the mitigation costs are significant and real, benefit estimates often diverge among studies. Two economic studies of the climate change impact on Florida's economy, Stanton and Ackerman (2007) and Harrington and Walton (2008), though different in approaches and methodologies, agree in the main conclusion-that the economic impacts will be significant. Stanton and Ackerman (2007) show that the losses from four climate change impacts-tourism reductions, hurricane damages, real estate losses, and increased costs of electricity generation-may reach $\$ 345$ billion (in 2006 U.S. dollars) by the end of the twenty-first century (Table 6 and Figure 3). In turn, Harrington and Walton (2008) find significant property value at risk of inundation due to sea level rises, as well as the potential for much increased storm damage from storm surges. The value of land at risk for 2080 represents a significant portion of the property wealth in the three coastal counties examined (Dade, Duval, and Escambia), more than $\$ 10$ billion in Dade County alone.

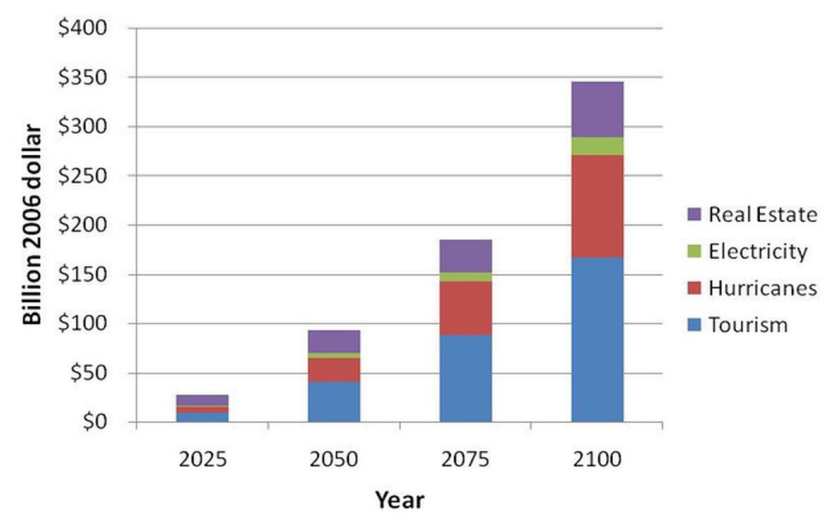

Figure 3. Costs associated with four major impacts of climate change on Florida's economy: The difference between rapid stabilization and business-as-usual scenarios.

The conclusion about significant economic impacts of climate change is supported by a review of economic studies by Ruth et al. (2007) conducted for the United States as a whole. The study offers five general conclusions:

1. Economic impacts of climate change will occur throughout the country. All sectors of the economy, most notably agriculture, energy, and transportation, will be affected. Essential infrastructure (such as water supply and treatment) will be impacted. Ecosystems, such as forests, rivers, and lakes, will suffer.

2. Economic impacts will be unevenly distributed across regions and within the economy and society.

3. Negative climate impacts will outweigh the benefits for most sectors that provide essential goods and services to society.

4. Climate change impacts will place strains on public sector budgets, particularly as the cost of infrastructure maintenance and replacement increases while economic losses due to climate change translate into lost tax revenues. 
5. Secondary effects of climate impacts can include higher prices, reduced income, and job losses.

This report strongly supports a call for action to avoid the most severe impacts of climate change, as well as to prepare for, and adapt to, those impacts that are unavoidable.

On the global level, the recent report of global business leaders to the World Economic Forum states: "While some uncertainties remain in applying a risk management perspective to the available information, we conclude that a reasonable approach is for all leaders of business and government to take action now" (CEO Climate Policy

Recommendations to G8 Leaders 2008).

\section{References}

- Bureau of Labor Statistics (BLS). 2008.

Databases, tables \& calculators by subject:

Consumer Price Index - All urban consumers.

Housing Series ID:

http://data.bls.gov/cgi-bin/surveymost

- Field, C.B., L.D. Mortsch, M. Brklacich, D.L. Forbes, P. Kovacs, J.A. Patz, S.W. Running, and M.J. Scott, 2007. Climate Change 2007:

Impacts, Adaptation and Vulnerability. Contribution of Working Group II to the Fourth Assessment Report of the Intergovernmental Panel on Climate Change, edited by M.L. Parry, O.F. Canziani, J.P. Palutikof, P.J. van der Linden and C.E. Hanson, 617-652. Cambridge, UK: University Press.

- Florida Governor's Action Team on Energy and Climate Change. 2008. Home Page.

http://www.flclimatechange.us/

- Harrington J. and T.L. Walton. 2008. Climate change in coastal areas in Florida: Sea level rise estimation and economic analysis to year 2080 . Florida State University, Tallahassee, FL. http://www.tcsurfrider.org/documents/ FLprojectedSeaLevelRise.pdf

- Intergovernmental Panel on Climate change (IPCC). 2007. Climate Change 2007: The Physical Science Basis: Summary for Policymakers. http://ipcc-wg1.ucar.edu/wg1/docs/

WG1AR4_SPM_PlenaryApproved.pdf

- Intergovernmental Panel on Climate Change (IPCC). 2007. Impacts, Adaptation, and Vulnerability. IPCC Fourth Assessment Report: Working Group II Report, Geneva, Switzerland. http://www.ipcc.ch/ipccreports/ar4-wg2.htm

- Intergovernmental Panel on Climate Change (IPCC). 2004. 16 Years of Scientific Assessment in Support of the Climate Convention, Geneva, Switzerland (December). http://www.ipcc.ch/pdf/10th-anniversary/ anniversary-brochure.pdf

- McCollum, B. 2007. Climate Change: The Bottom Line. Conversations on Climate Change. Tallahassee, FL (November 14).

http://www.floridaclimatechange.com/video.asp

- National Wildlife Foundation. 2006. An Unfavorable Tide: Global Warming, Coastal Habitats and Sportfishing in Florida. Report by the National Wildlife Foundation and the Florida Wildlife Foundation. http://www.nwf.org/globalwarming/pdfs/ AnUnfavorableTideReport.pdf

- Nordhouse, W.D. 2006. The economics of hurricanes in the United States. The American Economic Association Conference, Boston, MA (January) http://nordhaus.econ.yale.edu/hurr_122106a.pdf

- Pielke, R. A. and C. Landsea. 1998. Normalized hurricane damages in the United States: 1925-1995. Weather and Forecasting 13: 621-631.

- Ruth, M., D. Coelho, and D. Karetnikov. 2007. The U.S. economic impacts of climate change and the costs of inaction: A review and assessment. The Center for Integrative Environmental Research (CIER), University of Maryland, College Park, MD.

- Stanton, E.A. and F. Ackerman. 2007. Florida and Climate Change: The Costs of Inaction. Global Development and Environment Institute, Tufts University and Stockholm Environment 
Institute-US Center, Tufts University,

Medford, MA (November).

- Trimble, P.J., E.R. Santee, and C.J. Neidrauer. 1998. Preliminary estimate of impacts of sea level rise on the regional water resources of southeastern Florida. Journal of Coastal Research 26: 252-255.

- United States Environmental Protection Agency (U.S. EPA). 2007. Climate Change-Science: State of Knowledge. U.S. EPA, Washington, D.C. http://www.epa.gov/climatechange/science/ stateofknowledge.html

- United States Environmental Protection Agency (U.S. EPA). 2007b. Climate Change-Health and Environmental Effects: US Regions. U.S. EPA, Washington, D.C.

http://www.epa.gov/climatechange/effects/ usregions.html

- United States Environmental Protection Agency (U.S. EPA). 2002. Saving Florida's Vanishing Shores. U.S. EPA, Washington, D.C. http://www.epa.gov/climatechange/effects/ coastal/saving_FL.pdf

-Weyant, J.P. 2000. An Introduction to the Economics of Climate Change Policy. Report to the Pew Center on Global Climate Change, Stanford University, Palo Alto, CA.

- World Business Council for Sustainable Development. 2008. CEO climate policy recommendations to G8 leaders. July 2008. World Economic Forum, Geneva, Switzerland (July).

http://www.weforum.org/documents/initiatives/ CEOStatement.pdf 
Table 1. A1 and B2 scenarios developed by the IPCC.

\begin{tabular}{|lll|}
\hline \hline Scenario & \multicolumn{1}{c|}{ Assumptions } & \multicolumn{1}{c|}{$\begin{array}{c}\text { Global Average Temperature } \\
\text { Change for the 21st Century }\end{array}$} \\
\hline A1 & $\begin{array}{l}\text { Continuously growing population, regionally oriented } \\
\text { economic development, and slow technological change }\end{array}$ & $\begin{array}{l}\text { Increases by } 3.4^{\circ} \mathrm{C} \text { (likely range is } \\
2.0^{\circ} \mathrm{C} \text { to } 5.4^{\circ} \mathrm{C} \text { ) }\end{array}$ \\
B1 & $\begin{array}{l}\text { Rapid economic growth, but with changes toward service and } \\
\text { information technologies; population decline after } 2050 ; \\
\text { introduction of resource-efficient technologies; and global } \\
\text { economic, social, and environmental stability }\end{array}$ & $\begin{array}{l}\text { Increases by } 1.8^{\circ} \mathrm{C} \text { (likely range is } \\
1.1^{\circ} \mathrm{C} \text { to } 2.9^{\circ} \mathrm{C} \text { ) }\end{array}$ \\
\hline Source: IPCC (2007). & \\
\hline \hline
\end{tabular}

Table 2. Two future climate scenarios for Florida based on Stanton and Ackerman (2007).

\begin{tabular}{|c|c|c|c|c|}
\hline Climate Scenario & 2005 & 2050 & 2075 & 2100 \\
\hline \multicolumn{5}{|c|}{ Annual Average Temperature (in degrees Fahrenheit above year 2000 temperature) } \\
\hline Rapid Stabilization Case & 0.6 & 1.1 & 1.7 & 2.2 \\
\hline Business-as-Usual Case & 2.4 & 4.9 & 7.3 & 9.7 \\
\hline \multicolumn{5}{|c|}{ Sea Level Rise (in inches above year 2000 elevation) } \\
\hline Rapid Stabilization Case & 1.8 & 3.5 & 5.3 & 7.1 \\
\hline Business-as-Usual Case & 11.3 & 22.6 & 34.0 & 45.3 \\
\hline Source: Stanton and Acl & & & & \\
\hline
\end{tabular}

Table 3. Effect of storm surge and sea-level rise on future damage costs (2006 U.S. dollars).

\begin{tabular}{|lccc|cc|cc|}
\hline \hline County & Hurricane & \multicolumn{2}{c|}{ Historical Data } & \multicolumn{2}{|c|}{$\begin{array}{c}\text { "Low-end" Sea Level } \\
\text { Rise Scenario (2080) }\end{array}$} & \multicolumn{2}{|c|}{$\begin{array}{c}\text { "High-end" Sea Level } \\
\text { Rise Ecenario (2080) }\end{array}$} \\
\cline { 3 - 8 } & & $\begin{array}{c}\text { Storm } \\
\text { Surge }\end{array}$ & $\begin{array}{c}\text { Damage } \\
\text { Cost }\end{array}$ & $\begin{array}{c}\text { Storm } \\
\text { Surge }\end{array}$ & $\begin{array}{c}\text { Damage } \\
\text { Cost }\end{array}$ & $\begin{array}{c}\text { Storm } \\
\text { Surge }\end{array}$ & $\begin{array}{c}\text { Damage } \\
\text { Cost }\end{array}$ \\
\hline & & (feet) & (dollars) & (feet) & (dollars) & (feet) & (dollars) \\
\hline Dade & Wilma & 7.00 & $\$ 2.21 \mathrm{~B}$ & 8.02 & $\$ 2.48 \mathrm{~B}$ & 9.13 & $\$ 2.90 \mathrm{~B}$ \\
Dixie & Dennis & 9.00 & $\$ 0.06 \mathrm{M}$ & 9.90 & $\$ 0.07 \mathrm{M}$ & 11.13 & $\$ 0.08 \mathrm{M}$ \\
\hline \hline
\end{tabular}


Table 3. Effect of storm surge and sea-level rise on future damage costs (2006 U.S. dollars).

\begin{tabular}{|c|c|c|c|c|c|c|c|}
\hline \multirow[t]{2}{*}{ County } & \multirow[t]{2}{*}{ Hurricane } & \multicolumn{2}{|c|}{ Historical Data } & \multicolumn{2}{|c|}{$\begin{array}{l}\text { "Low-end" Sea Level } \\
\text { Rise Scenario (2080) }\end{array}$} & \multicolumn{2}{|c|}{$\begin{array}{l}\text { "High-end" Sea Level } \\
\text { Rise Ecenario (2080) }\end{array}$} \\
\hline & & $\begin{array}{l}\text { Storm } \\
\text { Surge }\end{array}$ & $\begin{array}{l}\text { Damage } \\
\text { Cost }\end{array}$ & $\begin{array}{l}\text { Storm } \\
\text { Surge }\end{array}$ & $\begin{array}{l}\text { Damage } \\
\text { Cost }\end{array}$ & $\begin{array}{l}\text { Storm } \\
\text { Surge }\end{array}$ & $\begin{array}{l}\text { Damage } \\
\text { Cost }\end{array}$ \\
\hline & & (feet) & (dollars) & (feet) & (dollars) & (feet) & (dollars) \\
\hline Duval & Frances & 5.90 & $\$ 72.3 \mathrm{M}$ & 6.73 & $\$ 80.2 \mathrm{M}$ & 8.03 & $\$ 98.00 \mathrm{M}$ \\
\hline Escambia & Dennis & 12.00 & $\$ 70.7 \mathrm{M}$ & 13.13 & $\$ 84.5 \mathrm{M}$ & 14.13 & $\$ 95.00 \mathrm{M}$ \\
\hline Monroe & Wilma & 2.76 & $\$ 215.3 \mathrm{M}$ & 3.78 & $\$ 298 \mathrm{M}$ & 4.89 & $\$ 370.00 \mathrm{M}$ \\
\hline Wakulla & Dennis & 9.00 & $\$ 4.42 \mathrm{M}$ & 10.05 & $\$ 5.73 \mathrm{M}$ & 11.13 & $\$ 6.90 \mathrm{M}$ \\
\hline \multicolumn{8}{|c|}{$\begin{array}{l}\text { Source: Harrington and Walton (2008). } \\
B=\text { billion dollars } \\
M=\text { million dollars }\end{array}$} \\
\hline
\end{tabular}

Table 4. Value of land at risk based on Florida State University's county-specific sea-level rise estimates for 2080.

\begin{tabular}{|c|c|c|c|c|}
\hline County & $\begin{array}{l}\text { Sea Level Rise } \\
\text { Estimate }\end{array}$ & $\begin{array}{c}\text { Value of Lands at } \\
\text { Risk }\end{array}$ & Area at Risk & Per Acre Value \\
\hline & (inches) & (dollars) & (acres) & (dollars) \\
\hline Dade & 12.24 & $\$ 70.0 \mathrm{~B}$ & 15,330 & $\$ 0.46 \mathrm{M}$ \\
\hline Duval & 9.96 & $\$ 30.6 \mathrm{M}$ & 1,992 & $\$ 0.01 \mathrm{M}$ \\
\hline Escambia & 13.56 & $\$ 210.8 \mathrm{M}$ & 1,913 & $\$ 0.11 \mathrm{M}$ \\
\hline \multicolumn{5}{|c|}{$\begin{array}{l}\text { Source: Harrington and Walton (2008); } 2005 \text { U.S. dollar values are converted into } 2006 \text { values } \\
\text { using BLS (2008). } \\
\text { B = billion dollars }\end{array}$} \\
\hline
\end{tabular}

Table 5. Revenue from tourism industry in the two climate scenarios based on Stanton and Ackerman (2007) (in billions of 2006 U.S. dollars).

\begin{tabular}{|lcccc|}
\hline \hline Climate Scenario & $\mathbf{2 0 2 5}$ & $\mathbf{2 0 5 0}$ & $\mathbf{2 0 7 5}$ & $\mathbf{2 1 0 0}$ \\
\hline Rapid Stabilization Case & $\$ 161$ & $\$ 137$ & $\$ 460$ & $\$ 668$ \\
Business-as-Usual Case & $\$ 152$ & $\$ 277$ & $\$ 372$ & $\$ 501$ \\
Difference between scenarios & $\$ 9$ & $\$ 40$ & $\$ 88$ & $\$ 167$ \\
\hline \hline
\end{tabular}


Table 6. Costs associated with four major impacts of climate change on Florida's economy: The difference between business-as-usual and rapid stablization scenarios (in 2006 U.S. dollars).

\begin{tabular}{lrrrr|}
\hline \hline Sector & 2025 & 2050 & 2075 & 2100 \\
\hline Tourism & $\$ 9 \mathrm{~B}$ & $\$ 40 \mathrm{~B}$ & $\$ 88 \mathrm{~B}$ & \$167 B \\
Hurricanes & $\$ 6 \mathrm{~B}$ & $\$ 25 \mathrm{~B}$ & $\$ 54 \mathrm{~B}$ & $\$ 104 \mathrm{~B}$ \\
Electricity & $\$ 1 \mathrm{~B}$ & $\$ 5 \mathrm{~B}$ & $\$ 10 \mathrm{~B}$ & $\$ 18 \mathrm{~B}$ \\
Real Estate & $\$ 11 \mathrm{~B}$ & $\$ 23 \mathrm{~B}$ & $\$ 33 \mathrm{~B}$ & $\$ 56$ \\
Total & $\$ 27 \mathrm{~B}$ & $\$ 92 \mathrm{~B}$ & $\$ 184 \mathrm{~B}$ & $\$ 345 \mathrm{~B}$ \\
$\%$ of Projected Florida GSP & $1.6 \%$ & $2.8 \%$ & $3.9 \%$ & $5.0 \%$ \\
\hline $\begin{array}{l}\text { Source: Stanton and Ackerman } \\
\text { B = billion dollars } \\
\text { GSP }=\text { Gross State Product }\end{array}$ & & & & \\
\hline \hline
\end{tabular}

